Please do not remove this page

RMIT

UNIVERSITY

\title{
Using building simulation to model the drying of flooded building archetypes
}

Taylor, Jonathon; Biddulph, P; Davies, Michael; Ridley, Ian; Mavrogianni, A; Oikonomou, Eleni; Lai, Ka man https://researchrepository.rmit.edu.au/esploro/outputs/9921859051901341/filesAndLinks?institution=61 RMIT_INST\&index=null

Taylor, J., Biddulph, P., Davies, M., Ridley, I., Mavrogianni, A., Oikonomou, E., \& Lai, K. man. (2013). Using building simulation to model the drying of flooded building archetypes. Journal of Building Performance Simulation, 6(2), 119-140. https://doi.org/10.1080/19401493.2012.703243

Document Version: Submitted Version

Published Version: https://doi.org/10.1080/19401493.2012.703243

Repository homepage: https://researchrepository.rmit.edu.au

(C) 2013 International Building Performance Simulation Association (IBPSA)

Downloaded On 2023/04/26 19:40:37 +1000 
Thank you for downloading this document from the RMIT Research Repository.

The RMIT Research Repository is an open access database showcasing the research outputs of RMIT University researchers.

RMIT Research Repository: http://researchbank.rmit.edu.au/

\section{Citation:}

Taylor, J, Biddulph, P, Davies, M, Ridley, I, Mavrogianni, A, Oikonomou, E and Lai, K 2013, 'Using building simulation to model the drying of flooded building archetypes', Journal of Building Performance Simulation, vol. 6, no. 2, pp. 119-140.

See this record in the RMIT Research Repository at:

http://researchbank.rmit.edu.au/view/rmit:20608

Version: Submitted Version

Copyright Statement: (C) 2013 International Building Performance Simulation Association (IBPSA)

Link to Published Version:

http://dx.doi.org/10.1080/19401493.2012.703243 


\title{
Using building simulation to model the drying of flooded building archetypes
}

\author{
Jonathon Taylor ${ }^{1,2}$, Phillip Biddulph ${ }^{1}$, Michael Davies ${ }^{1}$, Ian Ridley ${ }^{1}$, Anna Mavrogianni ${ }^{1}$, \\ Eleni Oikonomou ${ }^{1}$, Ka man Lai $^{2}$ \\ ${ }^{1}$ The Bartlett School of Graduate Studies, UCL, London \\ ${ }^{2}$ Department of Civil, Environmental, and Geomatic Engineering, UCL, London
}

\section{Abstract}

With a changing climate, London is expected to experience more frequent periods of intense rainfall and tidal surges, leading to an increase in the risk of flooding. Damp and flooded dwellings can support microbial growth, including mould, bacteria, and protozoa, while the relative humidity can also impact the survival of pathogens deposited by the flood water. The amount of time flooded dwellings can remain damp will depend on the duration of the flood, the contents of the flood water, the drying conditions, and the building construction, meaning different buildings are more prone to lingering damp and opportunistic pathogen growth and persistence. The impact of flooding on buildings can be simulated using Heat Air and Moisture (HAM) models of varying complexity in order to understand how water can be absorbed by and dry out of the building structure. This paper describes the simulation of the drying of flooded building archetypes representative of the London building stock using the EnergyPlus based tool 'UCL-HAMT' in order to determine the relative drying rates of different built forms and envelope designs. A sensitivity analysis is performed on UCLHAMT to examine the uncertainty in drying rates in the model. Three different internal drying scenarios, representative of conditions where no professional restoration equipment is used, are simulated. The application of a mould model is used to predict the duration of mould growth risk following a flood on the internal surfaces of the different building types, providing an estimate of the duration of potential damp within typical flooded properties in London.

\section{Introduction}

Flooding in the UK is currently a significant problem, with 2.79 million properties located in areas at risk of flooding [DEFRA, 2010]. London is particularly vulnerable to tidal floods from the Thames, and fluvial and surface water floods from heavy precipitation. During the summer floods of 2007, 1,000 London households were flooded following heavy rainfall. It has been estimated that a 1 in 50 year rainfall event would lead to the flooding of 1 in 7 London buildings and damages of tens of billions of pounds [GLA, 2009], not to mention the health cost to the residents of the flooded properties. Small, localised floods caused by water mains are also a regular occurrence. The issue of flooding is expected to become more frequent due to rising sea levels and an increased frequency of rain storms predicted to occur with climate change [UKCP09, 2009]. 
The duration and extent of damp due to floodwater in flooded properties can lead to a number of health issues for the occupants. Flood-related dampness may lead to the growth of mould, bacteria, and protozoa on the building surfaces, and the release of harmful bioaerosols into the indoor air [Taylor et al., 2011]. Occupants that are moved or displaced from their flooded properties can also experience an increase in health problems [S. M. Tapsell and Tunstall, 2008]. Understanding the duration of damp within buildings under different drying scenarios can help to predict the potential risk to occupants following a flood in terms of exposure to harmful pathogens, or duration of displacement. Additionally, there is a lack of definitive data on what the best practice is for drying different types of buildings, and how 'dry' is defined [Pitt, 2007]. Understanding how microbial health risk changes as a flooded building dries may help to better inform current remediation practices.

Very few experiments have been performed to quantify the drying ability of different buildings and construction types. Escarameia et al [Escarameia et al., 2007] built a range of typical new-build wall and floor structures and exposed them to water in order to observe their leakage and drying rates. Flooding studies of physical structures has also been carried out internationally [af Klintberg et al., 2008; Aglan, 2005; Binda et al.; USACE, 1988]. Constructing physical structures is expensive, time consuming, is limited to testing a single scenario at a time, and is dependent on the accuracy of the moisture measuring equipment. Modelling of drying scenarios can offer insight into the drying ability of flooded structures without the significant limitations of physical studies.

Heat, Air, and Moisture (HAM) simulation offers the possibility to simulate the flooding and drying out of different structures. The tool 'Delphin' [Nicolai and Grunewald, 2006] has been used to study the absorption of water and the impact of different drying techniques on brick buildings following the floods in Dresden [Grunewald and Plagge, 2006]. 'UCL HAMT (Heat and Moisture Transfer)' has been used to simulate the drying of a flooded church as part of the EU-backed Noah's Ark project [EU, 2007]. Drying simulations have also been performed for the brick and stone walls of a historic building [Blades et al., 2004].

This paper introduces a modelling framework for simulating the impacts of flooding on buildings in the UK building stock. The objectives were to:

- Examine the differences in drying rate of different wall types in the UK building stock.

- Compare the differences in the drying rate of different built forms proposed for the UK building stock.

- Model the mould growth risk inside drying archetypical buildings with typical built form/fabric combinations that have not been professionally restored.

- Assess the uncertainty of the UCL-HAMT model to variations in material parameters through a differential sensitivity analysis.

Building archetypes from energy modelling were adapted for hygrothermal simulations. A winter flood with a nominal height of $0.5 \mathrm{~m}$, based on the modelled maximum height of a 1 in 100 year fluvial flood risk for Hackney, East London [Scott Wilson, 2010] was simulated using the HAM model UCL-HAMT for the building archetypes. Three different drying scenarios representing typical interventions instead of professional remediation were examined: an abandoned house with the windows closed and with air changing only through the permeability of the building fabric; a dwelling dried using natural ventilation through open windows; and a dwelling dried using open windows and with the central heating turned on. The mould model of Clarke [Clarke, 1998] was used to predict the risk of mould growth 
on the internal surfaces within the building and calculate the surface area prone to mould growth over time. This tool can be used in future studies to examine the potential health impacts of different flood events and drying practices, as well as optimising remediation techniques.

\section{Methodology}

\section{Building Stock Development}

Classification of the UK building stock has been widely used in order to develop models for energy demand. Building archetypes have been developed which classify buildings thermal properties based on assumptions about the built form of different types of buildings. Age has typically been used as an indicator of the type of wall in a property. Energy models use nominal values for wall thickness and thermal conductivity to calculate heat losses for building archetypes. Flood modelling requires adapting these archetypes to include hygrothermal material properties of the building envelopes.

The building stock archetypes used in this study were originally developed by Oikonomou [Oikonomou et al., 2011] (Figure 1). These archetypes consist of 15 of the most commonly occurring built form and dwelling age combinations within their research area (29\% of the Greater London Authority household spaces), as determined from the individual building level data provided by the Cities Revealed database [The Geoinformation Group, 2010]. Briefly, Geographic Information System (GIS) calculations were used to determine the average building footprints, while internal layouts were taken from floorplans based on the age and form of the buildings [Bruckmann and Lewis, 1960; Chown, 1970; Jensen, 2007; Muthesius, 1982; Paul, 1967; Woodman and Greeves, 2008]. Window sizes were calculated based on building footprints, as described by Chapman [Chapman, 1994]. Combined, these built forms account for $76 \%$ of the London domestic stock within their research area. Some dwellings were ignored, for example flats above ground level and those with shops underneath, as they would not be directly impacted by flood waters. To take into account the airflow and ventilation of the built forms, the whole buildings were considered.

The English Housing Condition Survey [EHCS, 2008] was analysed to identify the types of building envelope construction associated with each building archetype based on its age/built form classification (Figure 1). The dimensions of the material components and layers of the building fabric were estimated based on standard material sizes, the Building Research Establishment (BRE) Domestic Energy Model (BREDEM) [Anderson et al., 1985], existing archetypes [Allen and Pinney, 1989], and documented building trends [Emmitt, 2010; University of the West of England, 2009]. To reduce the number of simulations, all wall types consisting of less than $5 \%$ of the total number of walls for each age/structure combination according to the EHCS analysis were ignored, meaning timber framed and insulated concrete buildings were not modelled. The construction of building fabrics used in the model can be seen in Table 1 .

Internal masonry walls were constructed with either brick (pre 1960) or Autoclaved Aerated Concrete (AAC) (Post 1960). Ground floors were taken to be either solid concrete slabs or suspended wooden floors. There is no published information available on the proportion of 
solid versus suspended ground floors in the UK housing stock [ECI, 2005], so assumptions were made based the SAP U-Value calculation methodology which assumes buildings built after 1929 have solid floors. Above-ground timber floors and ceilings were based on Allen and Pinney (1989). A highly insulating roof with a $10 \mathrm{~mm}$ plaster internal surface was put on the dwellings, as it helped to prevent numerical problems during the simulation and individual roof differences were not considered critical to the results.

Current standardised material data (eg. [BSI, 2000]) provides moisture content at 50\% RH and $80 \% \mathrm{RH}$, which can be used to estimate the desorption behaviour of wet materials. However, an accurate moisture storage function at high water contents was considered to be critical for this study. Therefore, hygrothermal material data was taken from the WUFI database [IBP, 2007] and was chosen to be as close as possible to the parameters provided by the standards referred to, and to those expected to be found in the London building stock (eg. London Stock Bricks). Hygrothermal material data for glass fibre was taken from Hokio et al. [Hokoi and Kumaran, 1993] . 

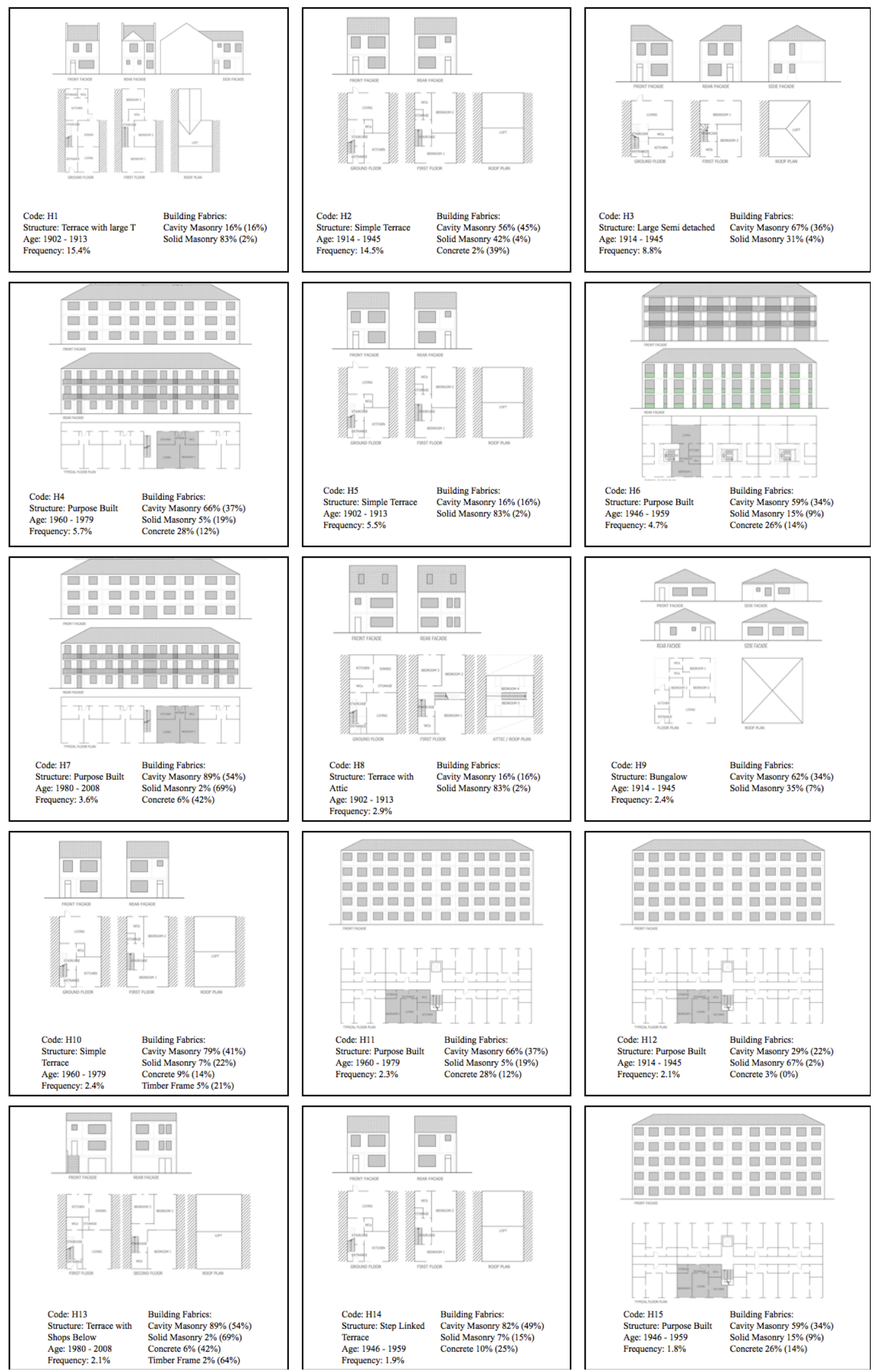

Figure 1. Building archetypes developed by Oikonomou et al (2011) and their relative frequency in the London building stock according to the Cities Revealed database. The EHCS analysis of the frequency of wall types according to built form and age is also included, with values in brackets indicating the percent of each wall type that is insulated. 
Table 1. Building fabric construction types for simulation. Listed from exterior (top) to interior (bottom).

\begin{tabular}{|c|c|c|c|c|c|}
\hline 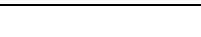 & \multicolumn{5}{|c|}{ Building Age } \\
\hline $\begin{array}{l}\text { Building Fabric } \\
\text { Construction }\end{array}$ & $1902-1914$ & $1914-1945$ & 1946-1959 & 1960-1979 & $1980-2008$ \\
\hline Solid Masonry & \multicolumn{2}{|l|}{$\begin{array}{l}220 \mathrm{~mm} \text { Brick } \\
10 \mathrm{~mm} \text { Plaster }\end{array}$} & $\begin{array}{l}335 \mathrm{~mm} \text { Brick } \\
10 \mathrm{~mm} \text { Plaster }\end{array}$ & & \\
\hline \multirow{2}{*}{ Masonry Cavity } & \multirow{2}{*}{$\begin{array}{l}\text { 102mm Brick } \\
50 \mathrm{~mm} \text { Air } \\
102 \mathrm{~mm} \text { Brick } \\
\text { 10mm Plaster }\end{array}$} & \multirow[t]{2}{*}{ or } & \multirow{2}{*}{$\begin{array}{l}\text { 102mm Brick } \\
\text { 50mm Glass Fibre } \\
\text { 102mm Brick } \\
\text { 10mm Plaster }\end{array}$} & $\begin{array}{c}102 \mathrm{~mm} \text { Brick } \\
\text { 50mm Glass Fibre } \\
\text { 102mm AAC } \\
\text { 10mm Plaster }\end{array}$ & $\begin{array}{l}102 \mathrm{~mm} \text { Brick } \\
\text { 100mm Glass Fibre } \\
102 \mathrm{~mm} \text { AAC } \\
\text { 10mm Plaster }\end{array}$ \\
\hline & & & & \multicolumn{2}{|c|}{$\begin{array}{l}\text { 102mm Brick } \\
50 \mathrm{~mm} \text { Air } \\
102 \mathrm{~mm} \text { AAC } \\
\text { 10mm Plaster }\end{array}$} \\
\hline Solid Concrete & \multicolumn{5}{|c|}{$\begin{array}{l}\text { 70mm Concrete } \\
\text { 60mm Concrete (no diffusion) } \\
\text { 70mm Concrete } \\
\text { 10mm Plaster }\end{array}$} \\
\hline Floor & $\begin{array}{l}\text { 70mm Concrete } \\
100 \mathrm{~mm} \text { Air } \\
12 \mathrm{~mm} \text { Wood }\end{array}$ & \multicolumn{4}{|c|}{ 70mm Concrete } \\
\hline $\begin{array}{l}\text { Internal Walls - } \\
\text { Masonry }\end{array}$ & \multicolumn{3}{|c|}{$\begin{array}{l}\text { 10mm Plaster } \\
102 \mathrm{~mm} \text { Brick } \\
10 \mathrm{~mm} \text { Plaster }\end{array}$} & \multicolumn{2}{|c|}{$\begin{array}{l}\text { 10mm Plaster } \\
102 \mathrm{~mm} \text { AAC } \\
10 \mathrm{~mm} \text { Plaster }\end{array}$} \\
\hline
\end{tabular}

\section{Modelling}

\section{Flood Modelling Considerations}

Liquid water movement into porous building materials is driven by capillary conduction, surface diffusion, hydraulic flow, electrokinesis, and osmosis. Capillary conduction is caused by suction forces created by surface tension in the capillary pores. Surface diffusion describes the spread of water molecules from areas of high concentration to areas of low concentration through random motion, and can be treated as part of the liquid transport in HAM models. Electrokinesis, and osmosis are generally ignored in HAM modelling due to their very small effects in water movement. Hydraulic flow includes movement due to gravitational forces and pressure from heads of liquid water, which are often ignored in HAM modelling, but can have an important role in the modelling of floods.

\section{Gravity}

The gravitational forces on liquid water inside small-pored building materials are significantly less than the capillary forces [Straube, 2002]. This is due to the inverse relationship between capillary pressure and the radius of the capillaries within the materials. As pore sizes increase, the capillary pressures reduce and the relative effects of gravity become more apparent (Table 2). Gravity-driven liquid flow can be important for the modelling of the movement of water in large pored materials or non-capillary active materials, where capillary pressures are not dominant or do not exist. One such material is glass fibre insulation. Fibrous insulation is non-capillary active due to the fibrous nature of the material, and the effects of gravity can be seen following immersion in water [Tagg et al., 2007]. Fully saturated fibrous insulation in vertical orientation has been observed to dry in 
two stages. In the first stage, gravitational drainage occurs within a few hours, leaving a top layer of material with a moisture content of $3-5 \%$ by volume, and a lower 10 to $20 \mathrm{~cm}$ layer of saturated material [Sandberg, 1987]. In the second stage, this lower section dries over a period of months through water vapourisation and diffusion of the vapour out of the material.

Gravitational drainage of water away from the building fabric requires assumptions regarding the drainage ability of the bottom boundary conditions. If the boundary is provided with a damp-proof layer, then certain materials can exhibit an accumulation of water towards the base of the structure.

\section{Head Pressure}

Like with gravity, the impact of liquid pressure on a building material relative to capillary pressures will depend on the material characteristics. Capillary pressures in small pored material tend to be much higher than the pressures found under a head of water at depths one would expect from a flood (eg. under $2 \mathrm{~m}$ ). This impact of pressure has been described previously [Hall and Hoff, 2002], where the water sorptivity of a clay brick increases by less than $50 \%$ under $100 \mathrm{~m}$ head of water. Like with gravity, the influence of pressure heads pressure relative to capillary pressure will depend on the pore diameter.

Table 2. Comparison of hydrodynamic pressures in flooded materials

\begin{tabular}{|l|c|c|c|c|}
\hline & $\begin{array}{c}\text { Mean Pore diameter }(\mu \mathrm{m})[\text { Blondeau } \\
\text { et al., 2003] }\end{array}$ & $\begin{array}{c}\text { Capillary } \\
\text { Pressure (Pa) }\end{array}$ & $\begin{array}{c}\text { Hydrostatic pressure }(0.5 \mathrm{~m} \\
\text { Head)(Pa) }\end{array}$ & $\begin{array}{c}\text { Gravitational Pressure }(0.5 \mathrm{~m} \\
\text { Height)(Pa) }\end{array}$ \\
\hline Brick & 1.98 & $1.47 \mathrm{E}+05$ & & \\
Concrete & 0.96 & $3.04 \mathrm{E}+05$ & & \\
Mortar & 0.07 & $4.17 \mathrm{E}+06$ & & \\
Gypsum & 1.41 & $2.07 \mathrm{E}+05$ & $4.90 \mathrm{E}+03$ & \\
$\begin{array}{l}\text { Board } \\
\text { Aerated }\end{array}$ & 66.03 & $4.42 \mathrm{E}+03$ & & \\
Concrete & 70.25 & $4.16 \mathrm{E}+03$ & & \\
$\begin{array}{l}\text { Particle } \\
\text { Board }\end{array}$ & & & \\
\hline
\end{tabular}

\section{Salt and Sediments}

Flood waters can often contain appreciable levels of salts, particularly tidal floods. Salts in building materials can be found in dissolved in water or precipitated. Dissolved salts affect the liquid moisture behaviour, including liquid density and viscosity, and hygroscopic sorption and water retention behaviour by altering the surface tension and contact angle [Koniorczyk and Gawin, 2008]. The evaporation rate of the water from the structure into the surrounding air can also be reduced due to the vapour pressure of the salt. Precipitated salts alter the pore structure of the material, blocking pores and restricting water movement. Sediment within the floodwater can also change the pore structure, making surfaces harder to dry. Hygrothermal models with salts have been developed [Grunewald, 1999], but have not yet been included in UCL-HAMT and the effects are not considered in this study.

\section{Models}

No simulation package was known to be available that would allow both the simulation of water movement into a structure using a pressure head of water, and the whole-building 
simulation of the internal and external drying of the building. Therefore, two separate HAM models were used to simulate the flooding and drying of the buildings: Delphin 5.6 and UCLHAMT (Heat and Moisture Transfer). Delphin is a 2 dimensional HAM model capable of modelling the movement of liquid water into a material using water pressure as a driving potential for transport. Delphin was used to simulate the flooding of the wall and floor assemblies.

UCL-HAMT is a one dimensional water content gradient driven hygrothermal model capable of simulating the movement and storage of moisture within the building surfaces from the internal and external environments integrated into EnergyPlus Version 3.1.0. The model applies a finite element grid to the building fabric, allowing for the simulation of heat and moisture transfer across the external and internal walls and ground floors. Since the algorithm is integrated into EnergyPlus, whole building simulation can be used to simulate moist air movement through the property, while the hygrothermal model allows for simulation of moisture absorption of the non-flooded surfaces from the damp air. UCLHAMT has undergone some initial testing and validation according to the Common Exercises of the International Energy Agency [Woloszyn and Rode, 2008] with excellent agreements with the consensus solutions [Ridley et al., 2008]. UCL-HAMT was used to simulate the drying of flooded buildings. The required inputs for UCL-HAMT can be seen in Table 3.

\section{Flood simulations}

A flood height of $0.5 \mathrm{~m}$, based on the modelled maximum height of a 1 in 20 year tidal flood risk for Hackney, East London was chosen for this study [Scott Wilson, 2010]. Delphin was used to simulate a 24 hour flood in the external and internal walls and floor assemblies using materials selected from the Delphin material database that were similar to those used in the rest of the study. It was assumed that water penetrated the building surfaces from both the interior and exterior sides. Water was assumed to fill the cavity instantly due to the presence of airbricks and cracks in the exterior and interior sheaths of the wall, and the observation that water is able to penetrate a wall soon after flooding commences [Tagg et al., 2007]. The flooding simulations took into account the potential impact of the head of pressure $(0.5 \mathrm{~m})$, while a moisture source was used to simulate the presence of water inside wall cavities, meaning water absorption was considered from external, internal, and internal cavity surfaces.

The simulations in Delphin provided an estimate of the amount of water penetration into building surfaces. The combined heat and moisture finite element algorithm in EnergyPlus UCL-HAMT was used to model drying. Building surfaces were divided into vertical 'flooded' and 'non-flooded' sections in UCL-HAMT, and the results of the Delphin simulations of water movement into the wall and floor fabrics were then used to approximate the water content levels for the $0.5 \mathrm{~m}$ high flooded sections. In cases where the Delphin simulation predicted different water contents within a single material layer of a wall (for example in Autoclaved Aerated Concrete (AAC), where the core remained drier than the surface), walls were divided into horizontal sections with different initial water contents. Dry sections of the buildings were prepared with an initial relative humidity of $80 \%$, chosen as the yearly average for the external weather file. UCL-HAMT automatically divided the walls into a course grid with 12 (solid 9” wall) to 22 (insulated AAC cavity wall) cells across the wall profile. 
To account for gravity, flooded sections of walls were divided into a further two sections. Walls that would be impacted by gravity (ie glass fibre-insulated walls) were modelled with an insulation moisture content at effective saturation $\left(0.98 \mathrm{~m}^{3} / \mathrm{m}^{3}\right.$ water) on the bottom $20 \mathrm{~cm}$, while the rest of the flooded section was modelled with an RH of $100 \%$ as per Sandberg [Sandberg, 1987]. Gravitational influences on other materials were ignored. Concrete walls can exhibit signs of self-sealing which causes liquid water to stop absorption at a certain distance into the material [Kunzel et al., 2008]. Because of this, concrete materials were divided into 2 different types - outer layers with liquid conductivity $70 \mathrm{~mm}$ thick, and a central core with liquid conductivity turned off and only vapour diffusion permitted.

Flooded and non-flooded sections of the same rooms were joined into a single zone so that there would be free air transfer between the flooded and unflooded sections. Air mixing within the zones was modelled using EnergyPlus Mixing/Well stirred model for room air. To simplify the model, cavities in the external wall and subfloor were modelled in certain assembly types by including a layer of air or insulation in the HAMT assembly. As a consequence, ventilation within these spaces was not modelled, an assumption which may impact drying behaviour, but is representative of a worst-case scenario where air bricks are blocked or not present.

The three different drying scenarios were modelled in order to predict the risk to occupants of remediators entering properties that have not had professional attention following a flood. An abandoned house was modelled with external windows and doors closed, heating turned off, and air change exclusively due to the permeability of the wall type (Solid, Filled and Unfilled Cavity) and surface area, as per the BRE [Stephen, 2000]. In the natural ventilation scenario, all external windows and internal doors were modelled as being constantly open, and air was considered to move in and out of the buildings due to the open windows and permeability of the walls. For the natural ventilation/heating scenario, the simulation was the same as with natural ventilation, except with electric baseboard heating on in the living room, kitchen, hallways, bathrooms, and bedrooms at a setpoint of $21^{\circ} \mathrm{C}$.

For all scenarios, airflow from zone to zone was modelled using the EnergyPlus Airflow network (Multizone without distribution), which simulated the movement of air from zone to zone throughout the buildings based on the air entering the property through open windows or the natural permeability. The airflow into the building due to permeability was modelled by specifying internal and external surface cracks with specified airflow properties. Air movement into the buildings was calculated using the wind pressure, the orientation of the building, and the location of the windows, if open.

In attached buildings, the presence of neighbouring properties was accounted for by shading the party walls from solar radiation and wind. The movement of heat and moisture from the walls into the internal and external environments was characterised by the convection coefficients. The indoor and outdoor heat transfer coefficients and vapour transfer coefficients were calculated by HAMT based on the airflow through the internal zones and the outdoor environment using the detailed surface convection algorithm.

External conditions were taken from a CIBSE Test Reference Year weather file for London (Figure 2). The flood simulations were started on January $1^{\text {st }}$, modelling winter floods on North/South oriented buildings only. The simulation timestep was 1 minute. The water content, relative humidity, and temperature were output from the surface cell of the interior side of the walls, floors, and ceilings inside the buildings as an hourly average. 
Table 3. Table of inputs for EnergyPlus UCL-HAMT model

\begin{tabular}{|l|l|}
\hline Exterior Conditions & Dry bulb temperature \\
& Wet bulb temperature \\
& Relative Humidity \\
& Ground Temperatures \\
& Wind Speed \\
& Wind Direction \\
& Solar and Environmental radiation \\
& Cloud Cover \\
\hline Interior conditions & Dry bulb temperature \\
& Wet bulb temperature \\
& Radiation \\
& Specified inputs of moisture at selected \\
& points and times (simulating gravity \\
& leakage) \\
& House Schedule \\
& Occupant Schedule \\
\hline Material Properties & Thickness \\
& Roughness \\
& Thermal Conductivity \\
& Density \\
& Specific Heat \\
& Thermal Absorbance \\
& Solar Absorbance \\
& Visible Absorbance \\
& Porosity \\
& Initial Moisture Content \\
& Moisture Storage Function \\
& Liquid Transport Coefficient (suction) \\
& Liquid Transport Coefficient \\
(redistribution) \\
Water Vapour Diffusion Resistance Factor \\
& Moisture-Related Thermal Conductivity \\
\hline & Latitude and longitude \\
& Shading \\
& Terrain \\
& Geometry of construction (Exterior and \\
interior walls, windows, doors, floors) & Permeability of surfaces \\
& \\
&
\end{tabular}

Simulation duration took from 4-12 hours to simulate a single building on a $2.83 \mathrm{GHz}$ Intel processor, depending on the building structure and the complexity of the building fabric. In order to increase the speed of simulation, naïve parallelisation was used to run multiple simulations on a single quad-core computer. Additionally, multiple instances were run on the Amazon Elastic Compute Cloud (EC2), as per Hopkins [Hopkins et al., 2011]. 


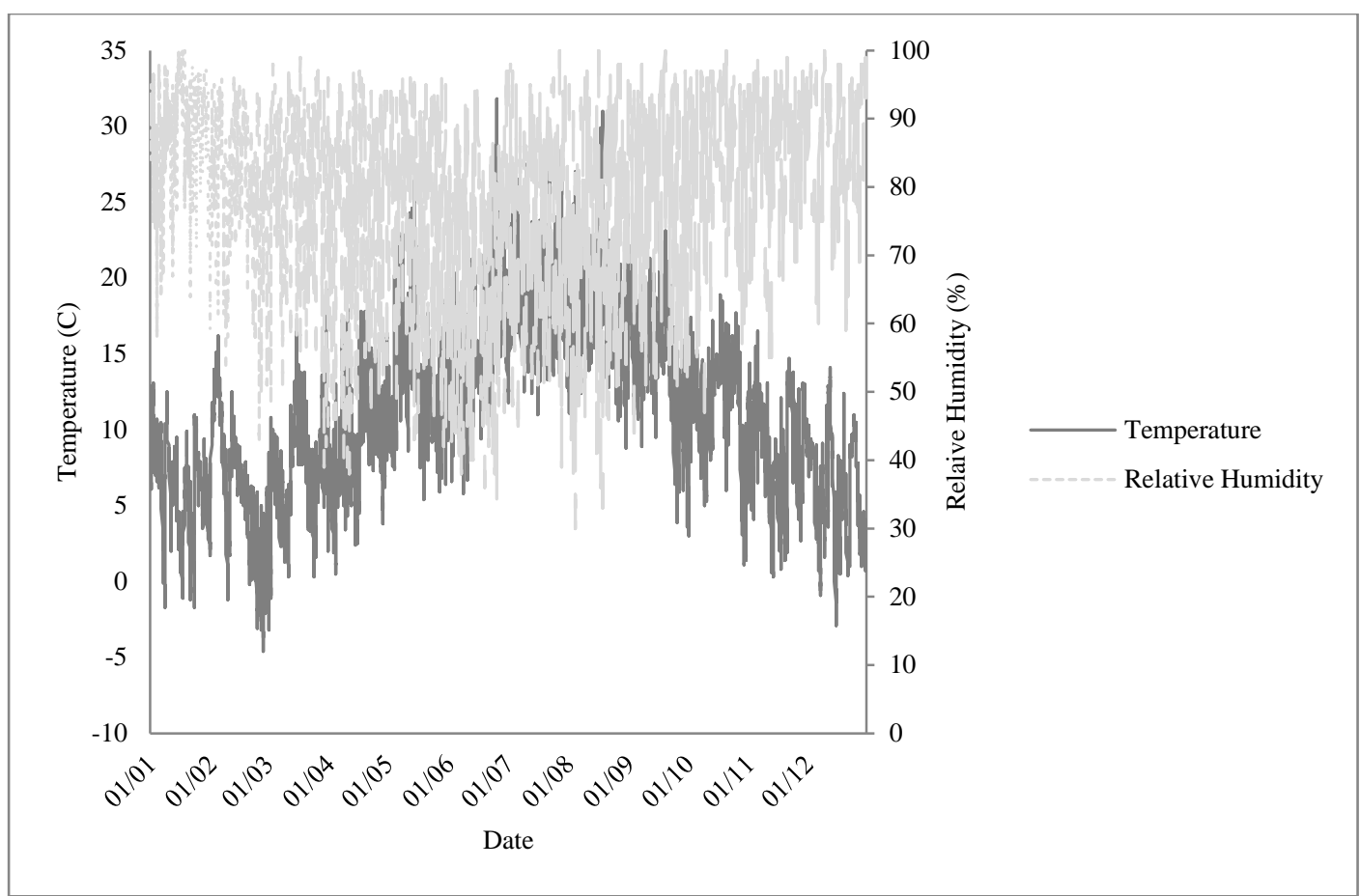

Figure 2. Temperature and RH values for the simulation weather file.

\section{Means of Comparison}

There is no suitable, agreed level of what constitutes a 'dry' property. The water content of the interior surfaces and within building cavities depends on the weather, operating conditions within the building, and the construction of the building fabric. Under typical conditions, different fabrics will contain different water contents. Because of this, the use of a mould model was used.

Models for predicting the risk of mould growth on building materials have been developed to run alongside HAM simulations. Clarke et al [Clarke, 1998] developed isopleths describing the minimum combinations of surface relative humidity and temperature that were required for the growth of mould species based on the literature. The Viitanen model is based on laboratory work which calculates the growth index of mixed mould species on softwood under steady and transient temperature and relative humidity [Viitanen et al., 2010]. The WUFI-Bio model [Sedbauer, 2002] is based on the hygrothermal behaviour of mould spores, and predicts the time to mould germination (in days) and growth (in $\mathrm{mm} /$ day) based on isopleths of the species and substrate categories. Moon [Moon, 2005] developed a probabilistic performance indicator for mould growth risk which takes into account the causal effect of building parameters and time of exposure.

In this study, surface relative humidity and temperature were used to calculate the risk of mould growth using the model developed by Clarke [Clarke, 1998] for Aspergillus versicolor over time. A Microsoft Excel macro was used to automate the import of the EnergyPlus output files and the total surface area of the building susceptible to mould growth was calculated. The reduction in surface area suitable for mould growth over time was smoothed by taking the 1 week rolling average in order to reduce the large fluctuations often seen in natural drying scenarios. The drying rates were compared between the different walls, building types and drying scenarios. 


\section{Sensitivity Analysis}

The variability of different data input parameters in the HAMT model will have an impact on the simulated drying of the structures. In order to quantify this variability, a Differential Sensitivity Analysis (DSA) of UCL-HAMT was performed to determine the uncertainty of the simulation results based on deviations in the hygrothermal material input parameters within the building fabrics, as well geometrical inputs including the building volume, window size, orientation, and permeability. The objective of the sensitivity analysis was to examine the individual sensitivities of the input parameters, and to gain an understanding of the uncertainty of the model outputs based on uncertainties in inputs. A separate sensitivity test was performed for each building fabric modelled in this paper.

As the whole building simulation of built forms with internal walls took a long time to simulate, a simplified building was used - in this case, a built form based on the BESTEST building [Judkoff and Neymark, 1995]. The result of the BESTEST simplification means the drying rates are not comparable with those of the individual built forms, however it allows for a better understanding of the impacts of specific parameters on drying. Surface constructions were given a saturated initial water content across the entire profile and up the full height of the wall, a simplification which meant that surfaces took longer to dry than those which were modelled with different water contents across the profile or smaller flood heights. The simulations were performed under constant conditions at $15^{\circ} \mathrm{C}$ at $50 \% \mathrm{RH}$ and with 60 time steps per hour. To calculate the sensitivity of the results to variations in the material parameters, the relative humidity in the surface cell of wall opposite the window was recorded.

The estimated standard deviation of the building material parameters are shown in Table 4 and the geometrical parameters in Table 5. Readers are referred to the UCL-HAMT documentation [EnergyPlus, 2010] for parameter definitions and model description. The standard deviations for the materials used in the sensitivity analysis are meant to represent the standard deviation of the materials found in the UK building stock. However, since little data exists that quantifies the variability of building materials, deviations had to be estimated from a range of sources. The presented deviations are best estimates based on deviations from materials within the WUFI material database, BS 10456 [BSI, 2000], the International Energy Agency (IEA) Annex 24 Final Report [Kumaran, 1996], and previous sensitivity analyses [Geving, 1997; Holm, 2001].

Table 4. Standard deviations for material parameters for sensitivity analysis.

\begin{tabular}{|c|c|c|c|c|c|c|}
\hline Parameter & Brick & Gypsum & AAC & Concrete & Spruce & Glass Fibre \\
\hline Thermal Conductivity & $10 \%$ & $10 \%$ & $10 \%$ & $5 \%$ & $5 \%$ & $10 \%$ \\
\hline Density & $15 \%$ & $15 \%$ & $15 \%$ & $15 \%$ & $15 \%$ & $15 \%$ \\
\hline Specific Heat Capacity & $5 \%$ & $5 \%$ & $5 \%$ & $5 \%$ & $5 \%$ & $5 \%$ \\
\hline Thermal Absorbance & $10 \%$ & $10 \%$ & $10 \%$ & $10 \%$ & $10 \%$ & $10 \%$ \\
\hline Solar Absorbance & $10 \%$ & $10 \%$ & $10 \%$ & $10 \%$ & $10 \%$ & $10 \%$ \\
\hline Visible Absorbance & $10 \%$ & $10 \%$ & $10 \%$ & $10 \%$ & $10 \%$ & $10 \%$ \\
\hline Porosity & $10 \%$ & $10 \%$ & $5 \%$ & $10 \%$ & $10 \%$ & $3 \%$ \\
\hline Moisture dependent moisture storage capacity @100\% RH & $15 \%$ & $15 \%$ & $15 \%$ & $15 \%$ & $15 \%$ & $15 \%$ \\
\hline Moisture dependent moisture storage capacity @ 80\% RH & $15 \%$ & $15 \%$ & $15 \%$ & $15 \%$ & $15 \%$ & $15 \%$ \\
\hline Liquid Transport Coefficient Suction & $15 \%$ & $15 \%$ & $15 \%$ & $15 \%$ & $15 \%$ & $15 \%$ \\
\hline Liquid Transport Coefficient Redistribution & $15 \%$ & $15 \%$ & $15 \%$ & $15 \%$ & $15 \%$ & $15 \%$ \\
\hline Moisture dependent vapor diffusion resistance factor & $20 \%$ & $20 \%$ & $20 \%$ & $20 \%$ & $20 \%$ & $10 \%$ \\
\hline
\end{tabular}




\begin{tabular}{|c|c|c|c|c|c|c|}
\hline Moisture dependent thermal conductivity & $15 \%$ & $15 \%$ & $15 \%$ & $15 \%$ & $15 \%$ & $15 \%$ \\
\hline Thickness & $10 \%$ & $10 \%$ & $10 \%$ & $10 \%$ & $10 \%$ & $10 \%$ \\
\hline
\end{tabular}

Table 5. Geometrical deviations of sensitivity analysis.

\begin{tabular}{|l|l|}
\hline & Standard Deviations \\
\hline Building Volume & $10 \%$ \\
\hline Window Size & $10 \%$ \\
\hline Building Orientation & $45^{\circ}$ \\
\hline Permeability & $10 \%$ \\
\hline
\end{tabular}

The standard deviations were used to perform a DSA [Lomas and Eppel, 1992] running simulations with material parameters varied plus or minus two standard deviations $(95 \%$ certainty) on each of the different wall types studied. The differences between the base case and deviated case were calculated and the negative and positive deviations added separately in quadrature. The uncertainties of the drying surfaces were graphed using Microsoft Excel.

\section{Results}

\section{Drying Simulations}

\section{Building Fabrics}

The different types of building fabrics simulated showed a wide range of drying times when dried in the same climate conditions. Figure 3 shows the decline in the moisture content of the different external wall types as they dry under naturally ventilated conditions. Thicker brick walls were found to dry slower than thinner walls, while the presence of a fibrous mineral insulation or AAC greatly increased the drying times of the walls. Solid concrete walls did not exhibit a large decline due to the low potential water content of concrete. Figure 4 shows the surface cells of the different external walls drying in the living room of built form H11 (60's and 70's walk up flat) under the same naturally ventilated conditions following the $0.5 \mathrm{~m}$ flood. Under naturally ventilated conditions, the $\mathrm{RH}$ of the surface cells of the walls were much more prone to the fluctuations in $\mathrm{RH}$ of the air used to ventilate the properties, and began to follow the trend exhibited in the weather file (Figure 2). For simplification, the fluctuations caused by the external weather file in preceding graphs of naturally ventilated scenarios have been smoothed by calculating a one week rolling average. 


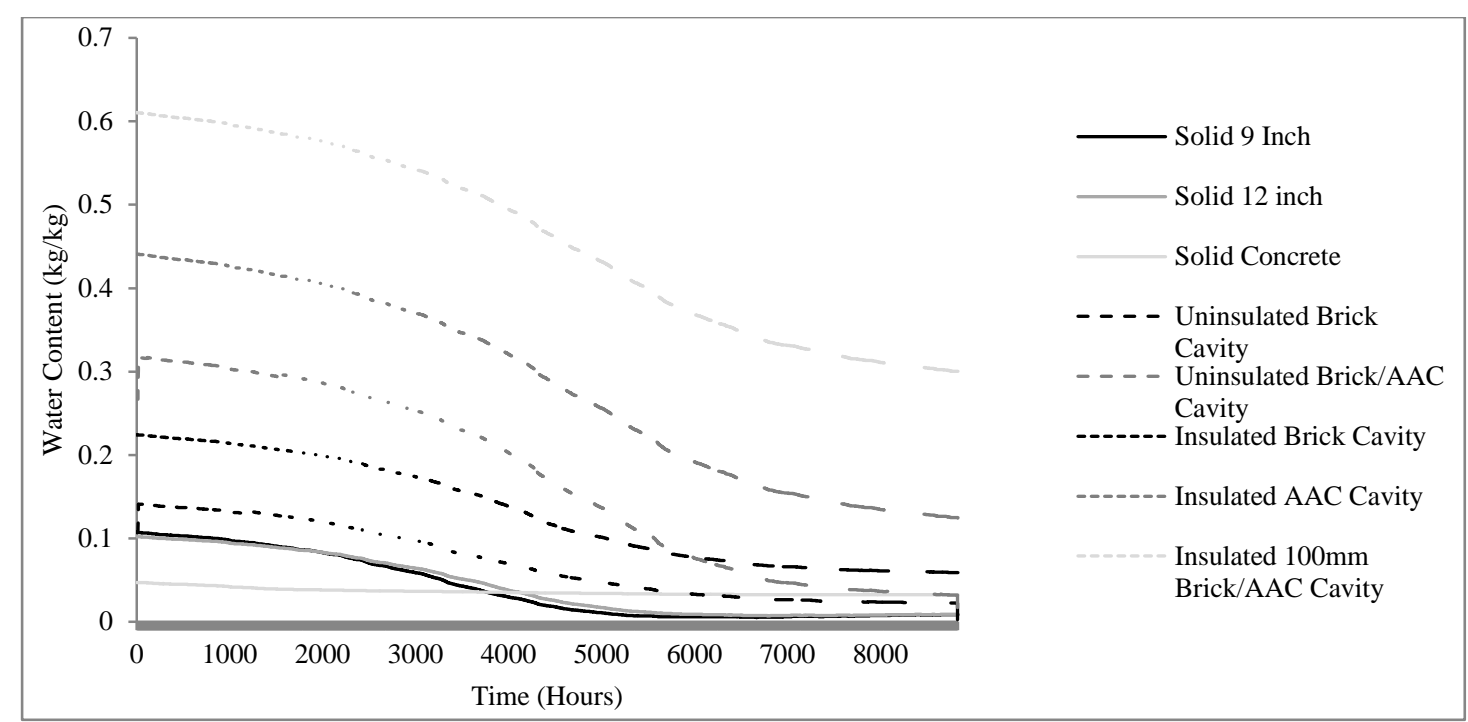

Figure 3. The moisture content of the whole walls $(\mathrm{kg} / \mathrm{kg})$ decreases as they dry through natural ventilation.

The internal surface of solid concrete floors were found to be worse than suspended wooden floors in their ability to dry, however data was not noted for the subfloor space which may remain damp. While the surfaces of solid brick and concrete walls could be expected to dry out under naturally ventilated conditions within $1-3$ months, mineral fibre and AAC walls were observed to take as long as half a year to dry on the surface.

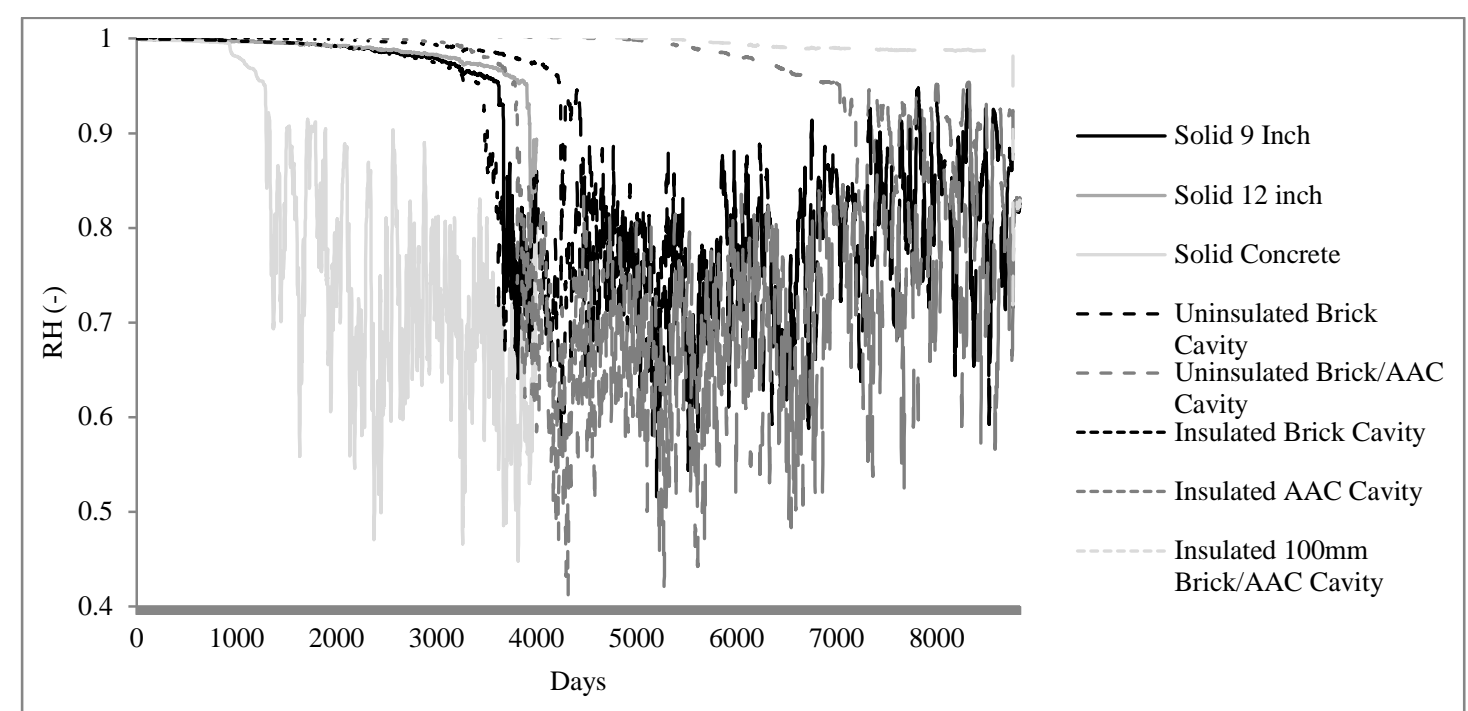

Figure 4. The decrease in surface relative humidity of walls as they dry through natural ventilation.

An examination of the results indicated the relative humidity and water contents of the surfaces of the walls did not necessarily reflect the water content throughout the wall as the cores of the walls remained wet longer than the surfaces. An example simulation of the relative humidity across the profile of a solid 9" brick wall and a mineral fibre insulated brick cavity wall drying using natural ventilation indicates that the mineral fibre retains moisture from floodwater throughout the year-long simulation time (Figure 5). 


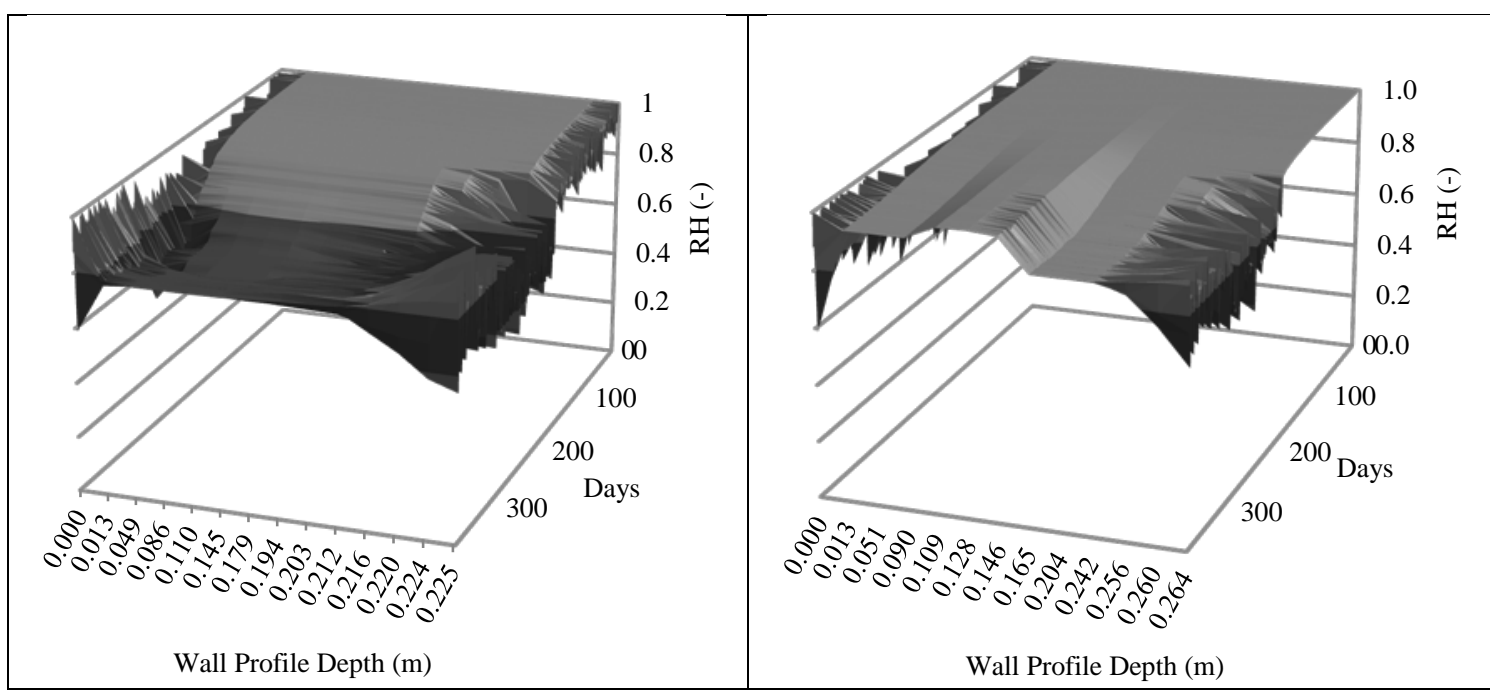

Figure 5. The cross section of a solid 9" brick wall (left) and an insulated brick cavity wall (right) drying under natural ventilation over time. The exterior of the walls are on the left and the interior on the right.

\section{Drying Scenarios}

Figure 6 shows an example of the reduction in the internal surface area suitable for mould growth in a bungalow with the three different drying scenarios. The modes represent the most common building fabric type - in this case uninsulated brick cavities, while the range represent the different types of building fabrics generally found in each archetype according to the EHCS analysis (Figure 1).

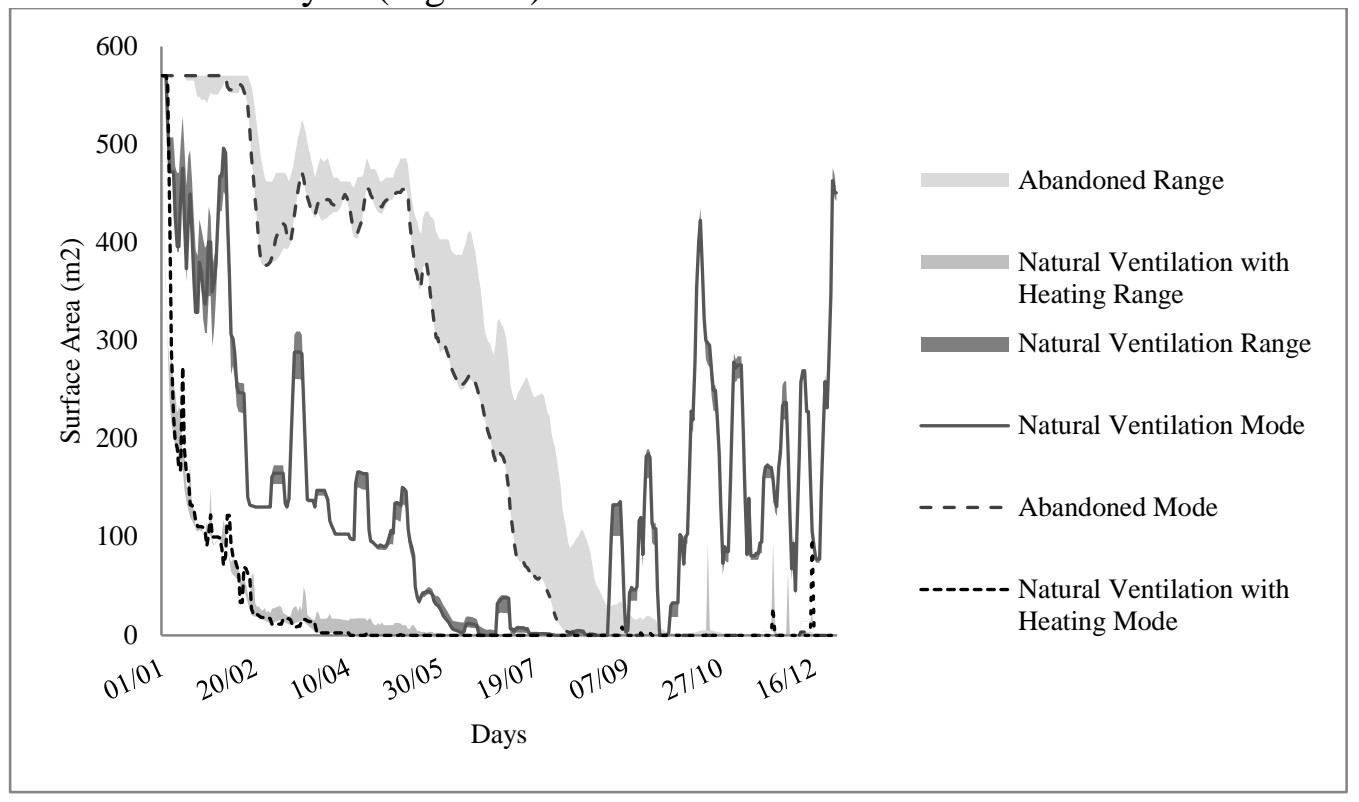

Figure 6. Difference in internal surface area at risk of mould growth for a bungalow with 9" solid brick walls according to treatment type.

The dwellings showed a wide variation in drying times according to the treatment provided. Buildings that were naturally ventilated dried much faster than the sealed buildings, which could often remain at risk for mould growth throughout the building for the entire year-long simulation. Heating the building using the central heating caused the fastest drying rate of 
the three scenarios modelled, with a rapid decrease in the conditions suitable for mould growth. With natural airflow, the differences in the drying rates between the wall types was minimised due to the convective airflow removing moisture from the internal surface of the walls, and the differences in drying rate observed in Figure 4 were minimized due to the small relative flood height. In all drying methods, the decrease of the damp surface area was limited by the concrete floor, which took a long time to dry.

\section{Built Form}

The relative humidity of all indoor surfaces was high immediately following the flood, including surfaces untouched by flood water. The surface relative humidity in first and second level rooms was as high as $99 \%$, indicating that a flood can impact the moisture levels on the surfaces throughout an affected building. The decline of the RH of the internal surfaces were found to vary between buildings and, indeed, between rooms of buildings. Figure 7 demonstrates the difference in drying rate of floors in the rooms of a bungalow, which indicates that smaller rooms dry slower than those in larger rooms with windows.

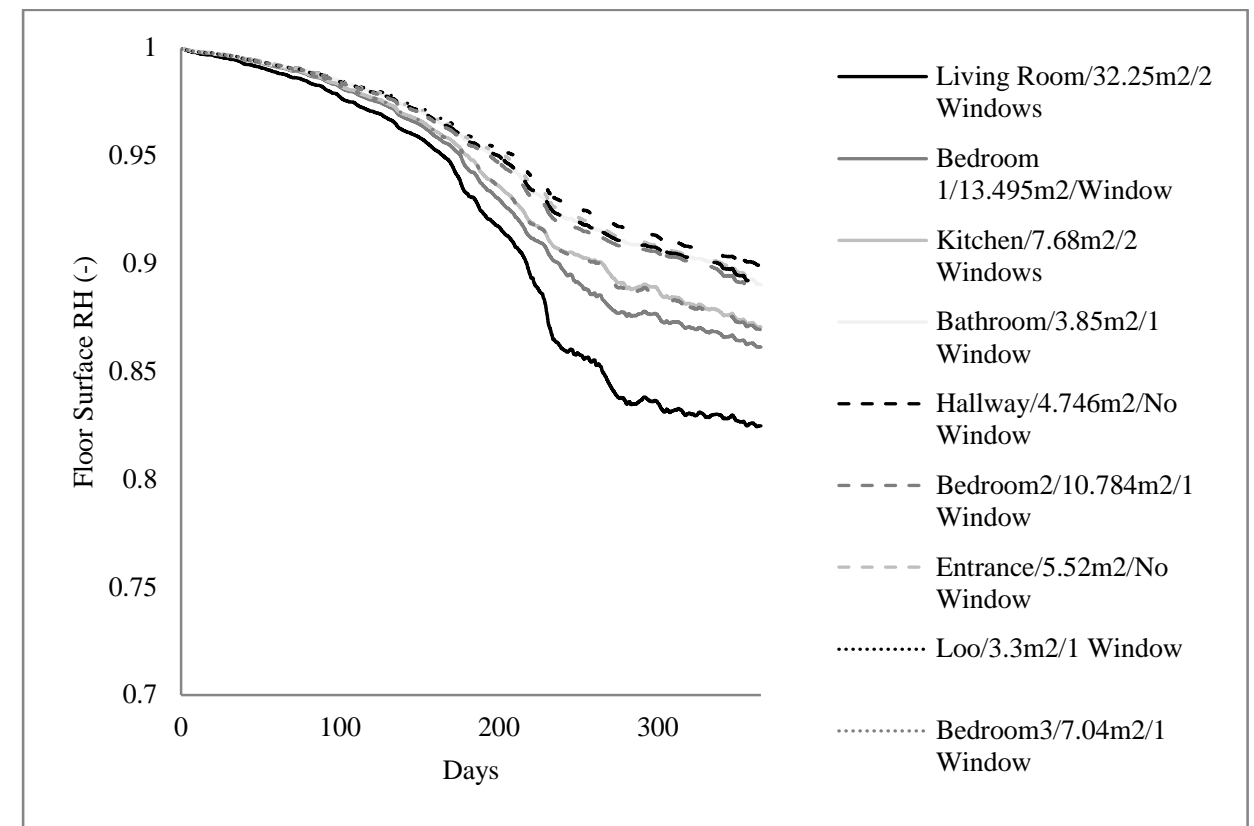

Figure 7. The drying of the surface of the floors in a bungalow using natural drying, for different rooms/ room footprint areas / and access to natural ventilation.

In addition, different built forms dried at different rates, depending on the drying scenario (Figure 8). Multi-storey buildings had a high initial surface area prone to mould growth as damp air moved around the buildings. The surface area prone to mould growth in these buildings declined relatively quickly when windows were open, compared to single-level dwellings flooded to the same height. In cases of abandoned buildings, purpose-built flats also performed poorly, while larger detached and semi-detached properties performed the best. 


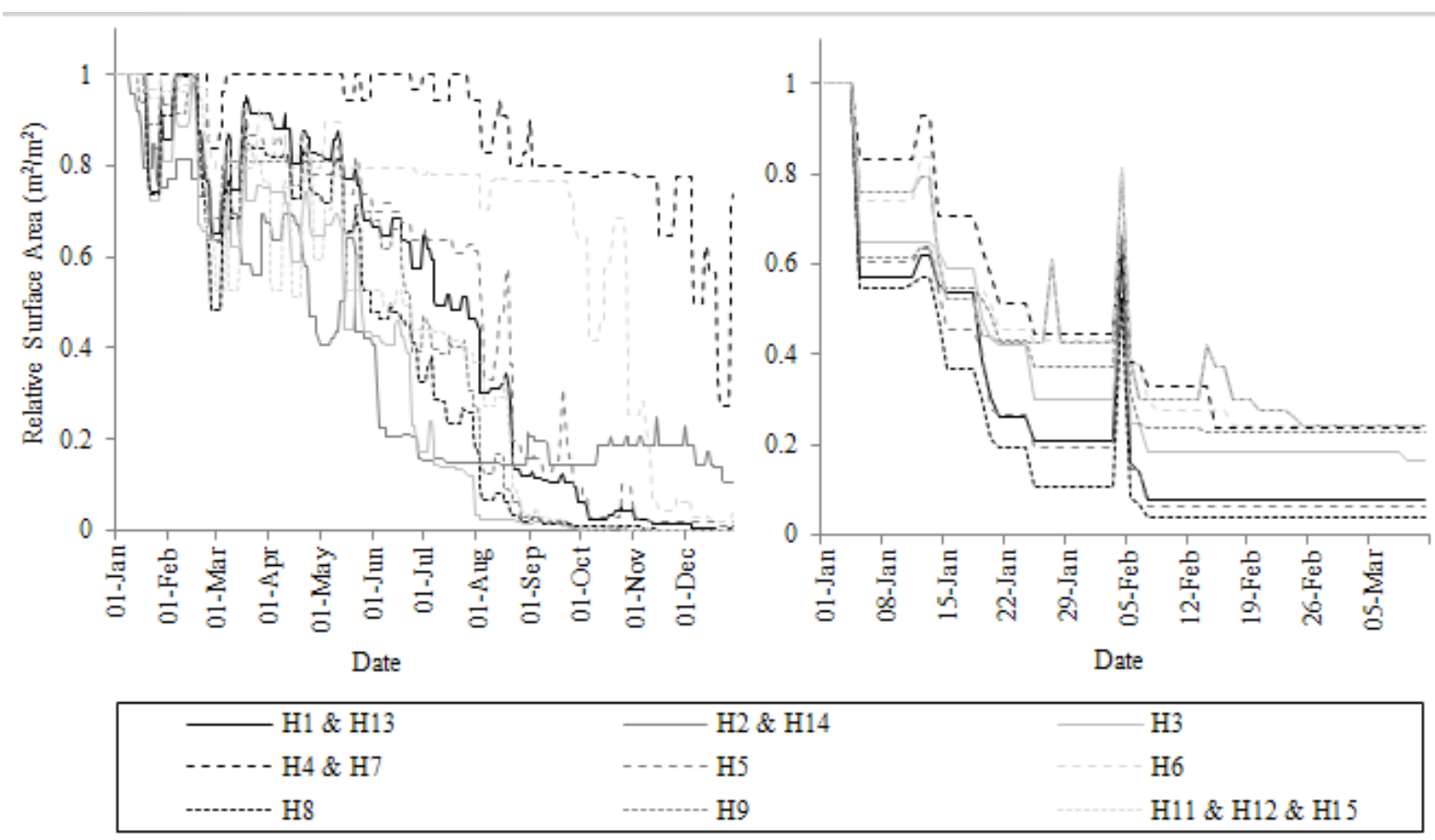

Figure 8. The decrease in relative surface area suitable for mould growth inside building archetypes with a 9” brick wall under abandoned (left) and natural ventilation (right) scenarios.

The reduction of surface area inside each of the flooded archetypes over time for natural drying and abandoned scenarios can be seen in Figure 9. Particular archetypes were found to be prone to long-term damp following flooding due to their unique combination of built form and typical building fabrics. Archetypes H4, H7, H10, and H11were found to present a risk of being highly susceptible to mould growth following flooding for a year following the flood event when abandoned. In the cases of dwelling $\mathrm{H} 4$ and H7, the most common wall type (mode) was found to be particularly hard to dry, increasing the risks inside these properties.

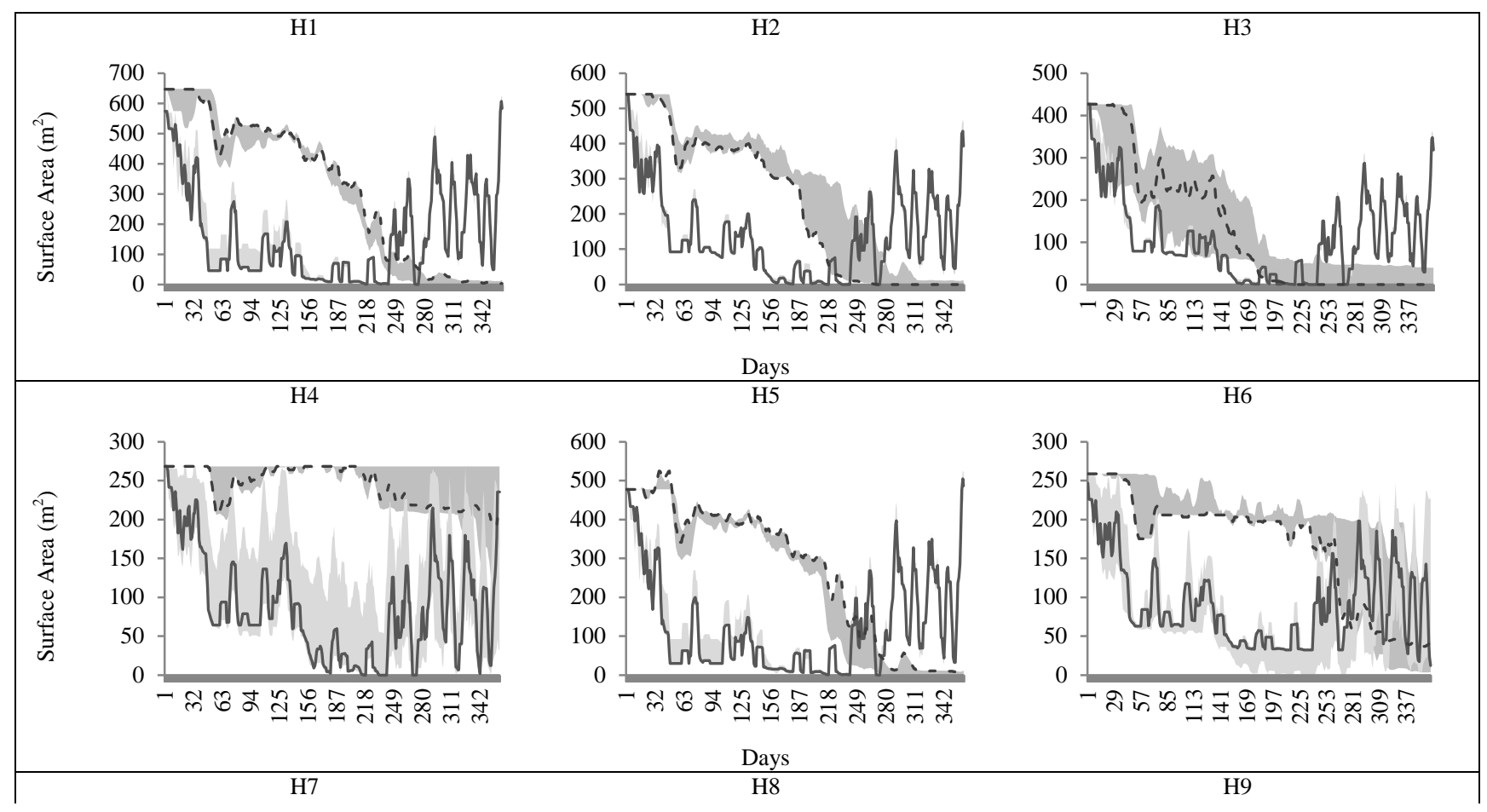




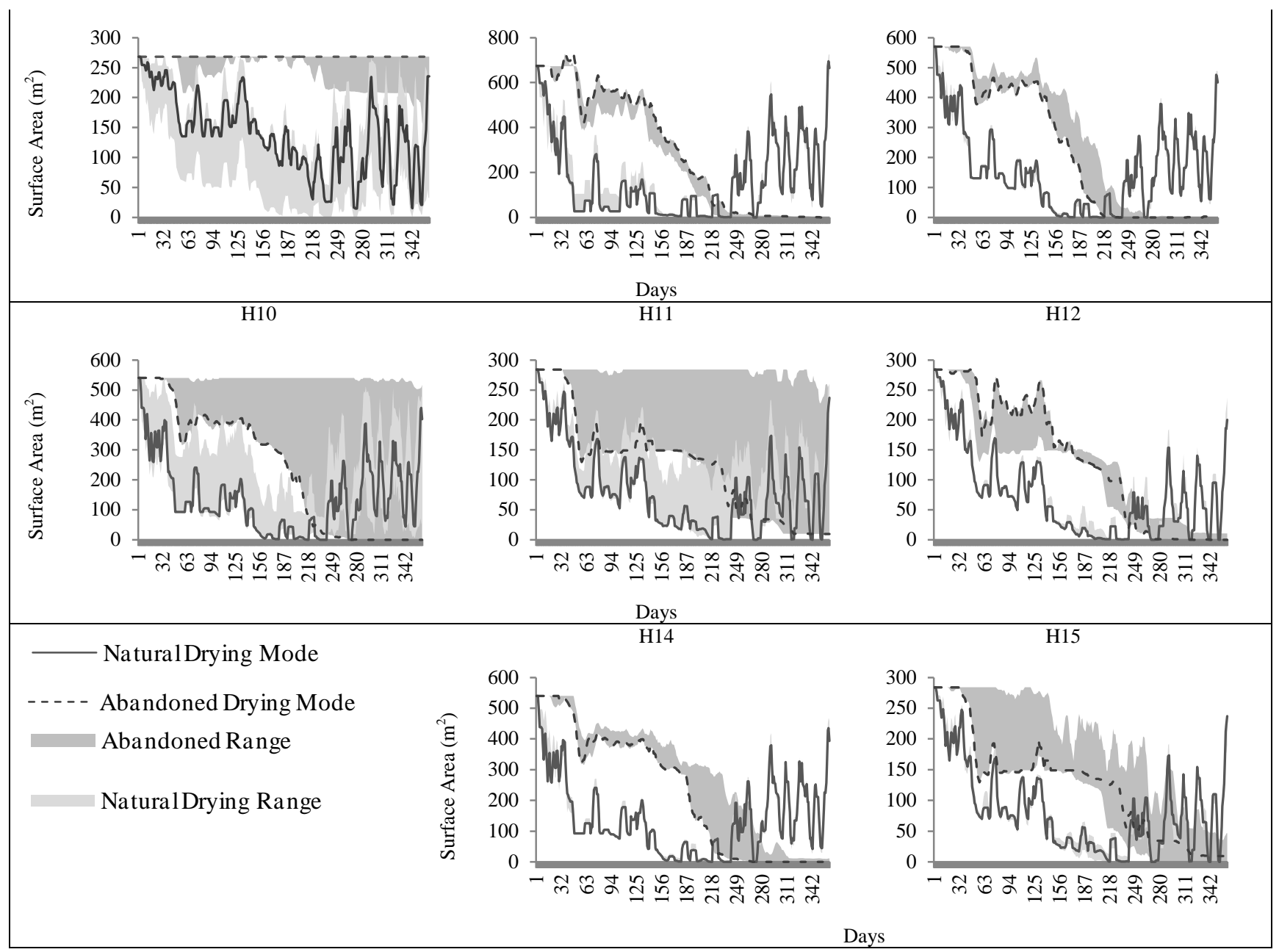

Figure 9. The decline in internal surface area suitable for mould growth over time for different built forms. The most frequent wall type for each building type is shown as the mode.

\section{Sensitivity Analysis}

The sensitivity analysis indicated that the material parameters with the greatest influence on the drying behaviour of the structures were the moisture storage functions, the liquid transport curves, and the vapour diffusion resistance factors. Other hygrothermal parameters, such as the material porosity, density, thermal conductivity, and solar absorbance were found to have a minimal effect on the drying behaviour. In terms of the geometrical properties, the air change rate had the greatest effect on the drying rate.

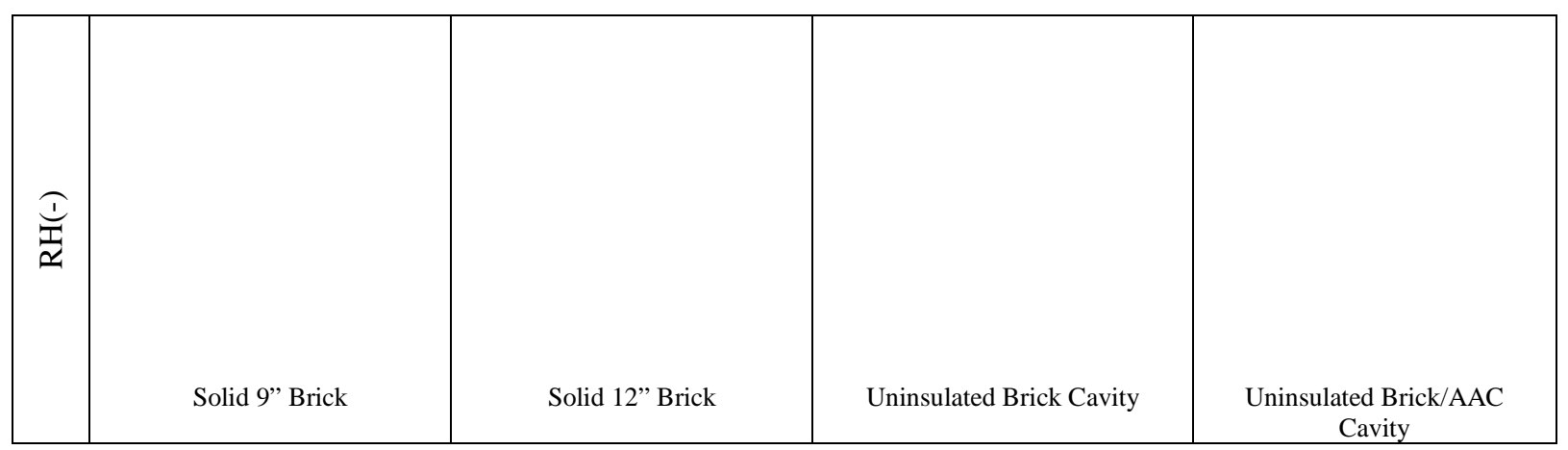




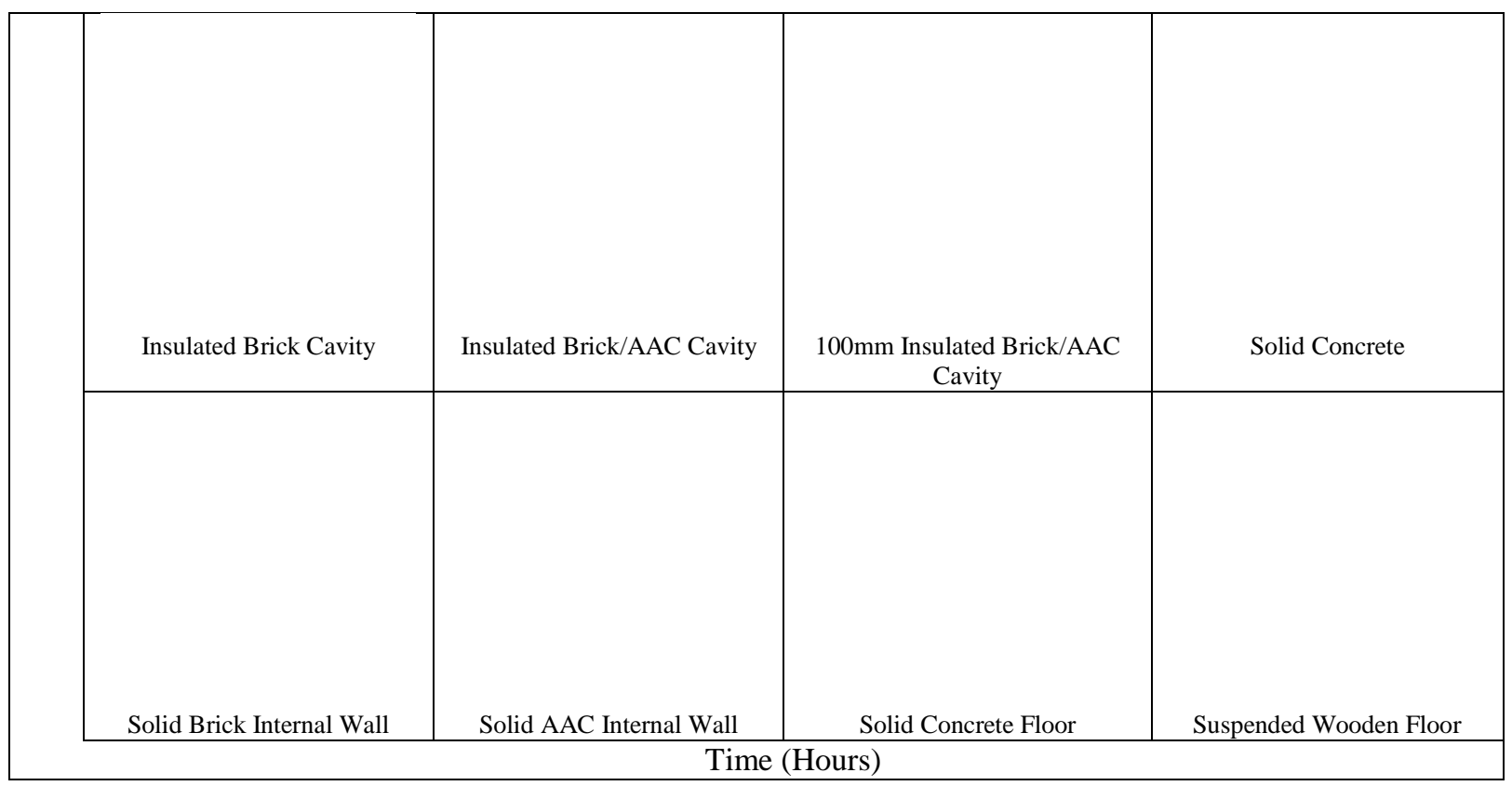

Figure 10. Sensitivity analysis showing the uncertainty in the drying rate of different wall types.

The results of the sensitivity test (Figure 10) suggest that material properties have a significant influence on the UCL-HAMT model, and that modelling studies should aim to use the most accurate material data possible. Despite the wide variation due to uncertainty in the sensitivity analysis results, different wall types were distinct in terms of their drying rates. Solid 9 inch brick walls, concrete walls, uninsulated cavity walls, and glass fibre insulated walls all showed different drying rates when the uncertainty in the models was taken into account.

\section{Discussion}

This paper presents the results of using a hygrothermal modelling approach to simulate the drying of different types of properties found in the UK domestic building stock. These results may be used to estimate the health risk inside untreated and treated properties, as well as perform the basis for future research into the best practices for the drying of affected buildings. While there are a number of variables not addressed in this study, such as the quality of the water and the presence of internal furnishings, this results provide insight into the drying of different built forms in the UK.

The relative drying times of walls were similar to those expected based on physical measurements from researchers and flood remediation organisations [Tagg et al., 2007]. Walls with fibrous insulation took significantly longer to dry than solid walls. This paper agrees with the recommendations that new constructions in flood-prone locations avoid mineral fibre insulation. Those entering flooded properties should have a good understanding of the wall types within the property and their ability to retain damp. In abandoned buildings, the differences between the relative drying ability of wall types was different due to the relative permeabilities of the wall types, as permeability determined the internal air change rate and therefore water vapour transport from the surface of the building fabrics.

There was a major difference between the drying rates of buildings depending on the postflood scenario modelled. Natural drying with central heating turned on provided the fastest 
drying rate for internal surfaces, while abandoned buildings showed a very poor drying ability. Where natural drying was employed, peaks of internal mould growth following surface drying were noted, and were caused by the weather conditions of the external air used to ventilate the interior. In many cases, such as those with fibre-glass insulated walls, the internal surfaces of abandoned properties could remain at risk for mould growth for the entire year-long simulation period. As a result, it is advisable that flooded homes be provided with as much ventilation as possible before remediation workers can restore the property. Heating the properties using central heating helped dry the internal surfaces when used alongside natural ventilation, however the trade-off between the economic cost of constantly heating the house with the windows open may make this prohibitive. Understanding the treatment history of the building can help clarify the risks present to those entering the property.

In addition to the wall type, naturally ventilated buildings showed differences in drying based on the potential airflow through the interior of the building. Smaller rooms without or with limited direct external ventilation, such as the hallways, bathrooms, and entrances of the bungalow, were found to dry slower than those with windows. Of the types of buildings studied here, purpose-built flats were found to dry slower than other structures using natural ventilation, which is likely due to the flood height representing a larger proportion of the total building surface area, the lack of exposure of the flooded building fabric to solar radiation and wind on the shared walls, and limited window space and airflow potential.

For sealed buildings, drying depended on the proportion of the flooded surface areas relative to the total surface area, the wall type, the permeabilities of the different wall types, and the surface area of the building exposed to external conditions and capable of permeable air exchange with the dry outdoor air. The worst performing buildings for drying under abandoned conditions were flats, particularly post-war and recent flats, and terraces. Particular archetypes that were found to be prone to mould growth for extended period following a flood due to their combination of built form and dominant wall type were 19601979 Purpose-Built Flats (H4 and H11), Post 1980 Purpose-Built Flats (H7), and 1960-1979 Terraced Buildings (H10). Purpose built flats are also the types of accommodation most common among low-income residents, suggesting that long-term damp may affect those least likely to be insured or unable to temporarily re-locate. Low income is also a significant factor in the susceptibility of a population to post-flood health effects [S.M. Tapsell et al., 2002]. With the move towards energy-efficient building methods buildings are becoming more airtight, insulation is becoming the norm, and natural permeability is being reduced. This suggests that modern properties may be prone to serious mould issues if left sealed.

The results of the sensitivity analysis indicate that there are distinct differences between the drying rates of certain wall types even when the uncertainty in material parameters is taken into account. In addition, the air change rate of the buildings is an important factor dictating the ability of a building to dry out, as determined by the window size and wall permeability. DSA is dependent on the assumption that the parameters are distributed normally around the base-case, and that the sensitivity of individual inputs are independent of the value of other inputs. This is not strictly true in complex hygrothermal systems, but is reasonable with small changes in the input parameters, and DSA has been used to assess other water contentdriven hygrothermal models [Holm, 2001].

There were some interesting results to the simulations worth noting. Relative humidity in unflooded locations, such as ceilings and above ground storeys, was found to be high enough to support mould growth following the flood. This was due to the movement of damp air 
throughout the building zones via the airflow network. This is notable, because the surface moisture content of walls in unflooded sections of a building are often used as a reference for what the 'dry' moisture levels should be during the building remediation [BSI, 2005]. These simulations suggest that this may be inappropriate.

The suggestion of lingering damp within the wall and floor cavities inside drying buildings suggests that damp may remain in buildings that are superficially dry. The water content levels on the interior surfaces were found to be non-representative of the levels throughout the wall, as conditions within the wall and on the surfaces of cavities could remain damp for extended periods. This is a concern, as it has been shown than mould spores can move from underfloor spaces and wall cavities into the internal air [Airaksinen et al., 2004; Liu, 2001; Suonketo and Pessi, 2000]. While the surfaces may appear to be dry, moisture will migrate to the surfaces of the wall over time, potentially leading to further mould growth once treatment has stopped. In cavity walls and subfloors, vapour removal by air change was not considered, meaning the potential for mould growth inside cavities cannot be estimated. This may lead to an over-estimation of the drying time of internal and cavity surfaces of these fabric types, however the simulations are intended to represent a worst-case scenario, for example, situations where air bricks or ventilators are blocks or absent.

Mould growth is a major problem following flooding, and buildings that showed a slow removal of moisture from the walls were more prone to mould growth. While isopleth-based models such as Clarke et al provide a useful indication of the lowest temperature and $\mathrm{RH}$ levels available for growth, an established mould colony can generate its own water sources by hydrolysing the material which it is growing on. Mould spores can resist desiccation, meaning drying to temporarily low conditions may not kill mould, and growth may recommence again in the future. Therefore, further research into the limits for mould spore survival is necessary in order to determine a 'safe' dry point for flooded buildings.

Flood water can contain a number of human pathogens, such as E. coli, Campylobacter, Enterococci, Leptospira, Shigella, Salmonella and Legionella species of bacteria [Brennan and Cole, 2009], which may be deposited on building surfaces and within cavities. The persistence of flood-borne pathogens on flooded surfaces can depend on the temperature and water activity on the surface, the nutrients and $\mathrm{pH}$ of the wall substrate and floodwater, and light [Kramer et al., 2006]. While the high relative humidity throughout flooded buildings indicates that there would be a strong probability of mould growth throughout the interior, the flooded sections of the building surfaces - where pathogenic flood-borne bacteria would be deposited -remained the wettest, longest. Some flooded walls were observed to have a surface RH above 97\% (considered at risk for bacterial growth [Viitanen et al., 2010]) for an extremely long time following flooding - a modern $100 \mathrm{~mm}$ glass fibre insulated AAC cavity wall in an abandoned flat, for example, remained above $97 \% \mathrm{RH}$ for the entire simulation period. Bacteria and mould may also produce toxins and metabolites, which can aerosolise and impact occupant health. Future research into modelling the survival of bacterial contaminants on indoor surfaces will be carried out as part of this research.

\section{Limitations of the Study}

The sensitivity test performed took into account the variances of different building fabrics, basic building geometry, and simple ventilation when simulating the drying of the walls. While this would account for the variances in the construction dimensions and hygrothermal 
material parameters of the walls for the simplified BESTEST construction, it does not account for any uncertainty in the more complex built forms of the building archetypes. Changes in the built form that could impact the airflow or air change rate in rooms will impact the drying rate, but modelling the wide range of variances possible in the specific building archetypes would be extremely difficult, and for this study has been ignored.

The presence of vapour barriers, internal and external finishings such as paint and rendering, and any flood-proofing has not been considered in these simulations. External render will add layer of hygrothermal material to the building fabric, impacting both the absorption of water and drying of the walls external surface. Internal coatings, such as paint, wallpaper, or tiles can impact the vapour diffusion resistance of a surface, and can be accounted for by adding a layer of still air to the surface. In these simulations, internal coatings were ignored due to the fact that water based paints and wallpaper offer minimal resistance to water vapour and drying. Additionally, UCL-HAMT is currently unable to model the absorption of water due to wind-driven rain. Heavy rainfall may impact the drying of the structures by penetrating the exterior surface of the walls.

The vapour transfer coefficient of the surfaces describes how water vapour can move from the building surfaces in to the surrounding air. This coefficient was calculated based on the airflow inside and outside the building, as determined by the airflow network and the outdoor windspeed. The model does not account for the restriction in air change caused by indoor furnishings.

In flood-prone areas, properties are often made 'flood-proof' by making them resistant to water penetration ('dry' flood proofing), or by minimizing the potential damage floodwater can cause ('wet' flood proofing). Perfect 'dry' flood proofing of a building is very difficult to achieve [Wingfield et al., 2005] and if it has not been performed seamlessly with all potential water access points sealed, then the property may take longer to dry out that it would otherwise due to the moisture barrier preventing water exiting the structure.

There are a number of limitations to modelling flooding using the current version of UCLHAMT. These include:

- The inability of the model to simulate the absorption of a head of water into the material, and the reliance on alternate models to simulate this stage.

- Ignoring gravitational forces on the movement of water within small pored materials.

- Ignoring the presence of salts or sediment in water and in building materials, which can impact the moisture transport behaviour of a material [Koniorczyk and Gawin, 2008], causing drying to take longer. These are particularly relevant for tidal or sewage floods.

- Ignoring the potential for capillary rise of the water within the building materials.

- HAM models assume a uniformity of hygrothermal properties throughout the materials, perfect contact between material layers, and do not take into to account cracks and poor workmanship, meaning that the simulation results reflect ideal constructions that will not exist in reality.

- Material parameters to describe liquid moisture behaviour for non-hygroscopic, noncapillary active materials like fibrous insulation is not widely available.

Despite the limitations of the model and the assumptions necessary to simulate something as complex as a whole building, UCL-HAMT was quickly able simulate a wide range of built 
forms, constructions, and drying scenarios that would not have been possible to experimentally test.

\section{Conclusions}

This work has demonstrated the potential for HAM models to simulate the flooding and drying of building archetypes. Dwellings were found to dry at different rates depending on the treatment, wall type, and built form. The fastest drying walls were solid concrete and brick walls and brick cavity walls, while glass fibre insulated cavities and cavities with an AAC inner leaf were found to be the worst performing, agreeing with previous physical studies. The drying methodologies had a significant impact, with natural ventilation with central heating drying the internal surfaces faster than those without heating. Abandoned buildings were found to remain damp on the inside for longer than the year-long simulation time for certain building types, suggesting that those entering flooded properties need to be aware of the building type and treatment history in order to assess the microbial risks inside the flooded dwelling. Built form was found to impact drying, with smaller rooms without direct outside air drying slower, and purpose-built flats drying slower than other dwellings. The ability of moist air to move around flooded properties meant that even following a $0.5 \mathrm{~m}$ flood, all surfaces within each building type were damp and capable of supporting mould growth.

Understanding the drying rates of specific properties under different scenarios can help inform flooding remediation companies of the most efficient and cost-effective means to dry flooded buildings. By using the risk of mould growth as an indicator of the risk to occupants living inside flooded buildings or workers entering an abandoned flooded building, we can predict the potential microbiological hazards people will be exposed to. Future work will involve combining simulations of the archetypes with floods of different heights, spatial building stock databases, and flood risk maps to predict the potential impact across flooded areas of London. This methodology can also be used for further studies into sizing the amount of drying equipment required for properties under different flood scenarios, and predicting the optimal distribution of equipment within a building. Contaminant dispersal algorithms, such as the Polluto model integrated into EnergyPlus (unpublished), can help to estimate the dispersal of airborne contaminants such as mould spores, mycotoxins and endotoxins, and microbial cell fragments which can lead to health problems for occupants within a building following a flood.

\section{Acknowledgements}

This research was carried out with funding from the EPSRC grant reference EP/G029881/1. The author acknowledges the assistance of the EPSRC funded 'Intrawise' project (PE/F007132/1) in producing this work.

\section{References}

af Klintberg, T., Johannesson, G and Bjork, F. 2008. Air gaps in building construction avoiding dampness and mould. Structural Survey. 26(3), 242.

Aglan, H. 2005. Field Testing of Energy-Efficient Flood-Damage-Resistant Residential Envelope Systems Summary Report. ORNL, Oak Ridge. 
Airaksinen, M., Kurnitski, J., Pasanen, P., and Seppänen, O. 2004. Fungal spore transport through a building structure. Indoor air. 14(2), 92.

Allen, E. J., and Pinney, A. A. 1989. A Set of Standard Dwellings - Details of Dimensions, Construction, and Occupancy Schedules. IHS BRE Press, Watford.

Anderson, B., Clark, A. J., Baldwin, R., and Milbank, N.O. 1985. BREDEM - BRE Domestic Energy Model: Background, Philosophy and Description. IHS BRE Press, Watford.

Binda, L., Cardani, G., and Zanzi, L. Nondestructive Testing Evaluation of Drying Process in Flooded Full-Scale Masonry Walls. J. Perform. Constr. Facil. 24 (5), 473-483.

Blades, N., Biddulph, P., Cassar, M., and Tuffnell, L. 2004. Modelling of climate change effects on historic buildings. UCL Centre for Sustainable Heritage, London.

Blondeau, P., Tiffonnet, A. L., Damian, A., Amiri, O. and Molina, J. L. 2003. Assessment of contaminant diffusivities in building materials from porosimetry tests. Indoor air. 13(3), 310-318.

Brennan, T., and Cole, G. 2009. Flood-Related Cleaning: Draft Report. Environmental Protection Agency, Atlanta.

Bruckmann, H., and Lewis, D. 1960. New Housing in Great Britain. Universe, New York.

BSI. 2000. BS EN12524: Building materials and products - Hygrothermal properties - Tabulated design values. British Standards Institution, London.

BSI .2005. PAS 64: Professional Water Damage Mitigation and Initial Restoration of Domestic Dwellings. British Standards Institute, London.

Chapman, P. 1994. A geometrical model of dwellings for use in simple energy calculations. Energy and Buildings. 21, 83-92.

Chown, I. 1970. Houses and Flats, in Metric Handbook : Planning and Design Data. Edited by D. Littlefield, Elsevier, Oxford.

Clarke, J. A., Johnstone, C.M. Kelly, N.J., McLean, R.C. Anderson, J.A., Rowan, N.J. and Smith, J.E. 1998. A technique for the prediction of the conditions leading to mould growth in buildings. Building and Environment. 34(1999), 515-521.

CONTAM. 2008. CONTAM 2.4c. National Institute of Standards and Technology, Gaithersburg, MD.

DEFRA. 2010. Flooding and Coastal Change. Department For Environment, Food, and Rural Affairs, London.

ECI. 2005. 40 Percent House. Environmental Change Institute, Oxford.

EHCS. 2008. English House Condition Survey, London.

Emmitt, S. 2010. Barry's Introduction to Construction of Buildings, 2 ed. Wiley-Blackwell, London.

EnergyPlus. 2010. EnergyPlus Engineering Reference. United States Department of Energy,

University of Illinois \& Ernest Orlando Lawrence Berkeley National Laboratory, Berkeley.

Escarameia, M., Karanxha, A. and Tagg, A. 2007. Quantifying the flood resilience properties of walls in typical UK dwellings. Building Services Engineering Research and Technology. 28(3), 249-263.

EU. 2007. Global Climate Change Impact on Built Heritage and Cultural Landscapes. European Union, Brussels.

Geving, S. 1997. A systematic method for hygrothermal analysis of building constructions using computer models. Proceedings of the building simulation. 2, 355-361.

GLA. 2009. Climate Change Adaptation Strategy. Greater London Authority, London.

Grunewald, J. 1999. Numerical simulation program DIM3.1 for coupled heat, air, salt, and moisture transport. In 10th International Symposium for building physics. Dresden, Germany. 
Grunewald, J., and Plagge, R. 2006. Rechnerische Bewertung von Trocknungsverfahren für hochwassergeschädigtes Mauerwerk. Bauphysik. 28(2), 88-95.

Hall, C., and Hoff, W. D. 2002. Water Transport in Brick, Stone, and Concrete. Taylor \& Francis, London.

Hokoi, S., and Kumaran, M. K. 1993. Experimental and Analytical Investigations of Simultaneous Heat and Moisture Transport through Glass Fibre Insulation. Journal of Thermal Insulation and Building Envelopes. 16, 263-292.

Holm, A. 2001. Drying of an AAC flat roof in different climates. Computational sensitivity analysis versus material property measurements. CIB W40. Wellington, NZ.

Hopkins, A., Lekov, A., Lutz, J., Rosenquist, G., and Gu, L. 2011. Simulating a Nationally Representative Housing Sample Using EnergyPlus. Ernest Orlando Lawrence Berkeley National Laboratory, Berkeley.

IBP. 2007. WUFI-2D, PC-Program for calculating the coupled heat and moisture transfer in building components. Fraunhofer Institut für Bauphysik, Stuttgart.

Jensen, F. 2007. The English Semi-detached House, Ovolo Publishing, Cambridge.

Judkoff, R., and Neymark, J. 1995. Building energy simulation test (BESTEST) and diagnostic method. National Renewable Energy Laboratory, Golden, Colorado.

Koniorczyk, M., and Gawin, D. 2008. Heat and Moisture Transport in Porous Building Materials Containing Salt. Journal of Building Physics. 31(4), 279-300.

Kramer, A., Schwebke, I. and Kampf, G. 2006. How long do nosocomial pathogens persist on inanimate surfaces? A systematic review. BMC Infectious Diseases, 6(1), 130.

Kumaran, M. K. 1996. Final Report, IEA-Annex 24, Task 3: Material Properties. IRC/NRC, Canada.

Kunzel, H., Holm, A. and Krus, M. 2008. Hygrothermal Properties and Behaviour of Concrete. WTA Almanach. 161-181.

Liu, D. L., and Nazaroff, W. W. 2001. Modeling pollutant penetration across building envelopes. Atmos. Environ. 35, 4451-4462.

Lomas, K. J., and Eppel, E. 1992. Sensitivity analysis techniques for building thermal simulation programs. Energy and Buildings. 19, 21-44.

Moon, H. J. 2005. Assessing Mold Risks in Buildings under Uncertainty. PhD Thesis. Georgia Intitute of Technology, Atlanta.

Muthesius, S. 1982. The English Terraced House. Yale University Press, London.

Nicolai, A., and Grunewald, J. 2006. Delphin. Dresden.

Oikonomou, E., Davies, M., Mavrogianni, A., Biddulph, P., Wilkinson, P. and Kolokotroni, M. 2011. Building characteristics as determinants of propensity to high indoor summer temperatures in London dwellings. Building and Environment. Submitted

Paul, S. 1967. Apartments, Their Design and Development. Reinhold Publishing Corporation, New York.

Pitt, M. 2007. Lessons learned from the 2007 floods. The Cabinet Office, London.

Ridley, I., Freeman, J., Biddulph, P., and Davies, M. 2008. Testing and Validation of UCL HAMT module for Energy Plus. UCL, London.

Sandberg, P. I. 1987. Thermal Resistance of a Wet Mineral Fiber Insulation, in Thermal Insulation: Materials and Systems. Edited by F. J. Powell and S. L. Matthews, pp. 394-404. American Society for Testing and Materials, Philadelphia. 
Scott Wilson. 2010. London Borough of Hackney Level 2 Strategic Flood Risk Assessment. Scott Wilson, London.

Sedbauer, K. 2002. Prediction of Mould Growth by Hygrothermal Calculation. Journal of Thermal Envelope and Building Science. 25(4), 321-336.

Stephen, R. 2000. Airtightness in UK Dwellings. Building Research Establishment, Watford.

Straube, J. F. 2002. Moisture in Buildings. ASHRAE Journal. 44:15-19.

Suonketo, J., and Pessi, A. 2000. The airflows and microbial contamination to indoor air from sandwich facade - case study. Healthy buildings 2000, Espoo, Finland, 2000.

Tagg, A., Escarameia, M. and Ortiz, J.M. 2007. Improving the Flood Resilience of Buildings Through Improved Materials, Methods, and Detail. CIRIA, Leeds.

Tapsell, S. M., and Tunstall, S. M. 2008. "I wish I'd never heard of Banbury": The relationship between place and the health impacts from flooding. Health \& Place. 14(2), 133-154.

Tapsell, S. M., Penning-Rowsell, E. Tunstall, S., and Wilson, T. 2002. Vulnerability to flooding: Health and social dimensions. Philosophical transactions. 360(1796), 1511.

Taylor, J., Lai, K.-M., Davies, M., Clifton, D., Ridley, I. and Biddulph, P. 2011. Flood management: prediction of microbial contamination in large-scale floods in urban environments. Environmental International 37(5), 1019-1029.

The Geoinformation Group. 2010. Cities Revealed. Cambridge.

UKCP09. 2009. UK Climate Projections 2009. Available at: http://ukclimateprojections.defra.gov.uk/ University of the West of England. 2009. Construction Web Site. Available at http://environment.uwe.ac.uk/video/cd_new_demo/Conweb/

USACE. 1988. Flood Proofing Tests - Tests of Materials and Systems for Flood Proofing Structures. US Army Corps of Engineers, Washington, DC.

Viitanen, H., Vinha, J., Salminen, K., Ojanen, T., Peuhkuri, R., Paajanen, L., and Lahdesmaki, K. 2010. Moisture and Bio-deterioration Risk of Building Materials and Structures. Journal of Building Physics. 33(3): 201-224.

Wingfield, J., Bell, M. and Bowker. P. 2005. Improving the Flood Resilience of Buildings Through Improved Materials, Methods, and Details: Review of Existing Information and Experience. CIRIA, Leeds.

Woloszyn, M., and Rode, C. 2008. Modelling Principles and Common Exercises. K.U. Leuven, Leuven.

Woodman, E., and Greeves, E. 2008. Home/Away: Five British Architects Build Housing in Europe: The Development of Housing in Britain 1870-2008. British Council, London. 